\title{
Deep-sea habitat heterogeneity influence on meiofaunal communities in the Gulf of Guinea
}

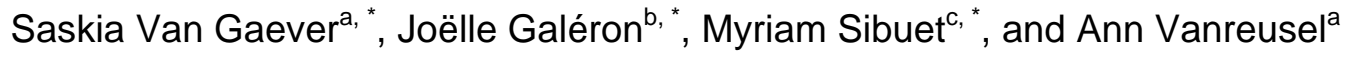 \\ ${ }^{a}$ Marine Biology Section, Department of Biology, Ghent University, Krijgslaan 281/S8, 9000 Ghent, Belgium \\ b Département Etude des Ecosystèmes Profonds (DEEP) IFREMER, Centre de Brest, BP 70, 29280 Plouzané, \\ France \\ c Institut Océanographique, Rue Saint-Jacques 195, 75005 Paris, France
*: Corresponding author : Saskia Van Gaever, Tel.: +32 0926485 25; fax: +32 0926485 98, email address : Saskia.VanGaever@UGent.be \\ Joelle.Galeron@ifremer.fr, msibuet@ifremer.fr, Ann.Vanreusel@UGent.be
}

\begin{abstract}
:
To estimate the degree of spatial heterogeneity of benthic deep-sea communities, we carried out a multiple-scale (from m's to $200 \mathrm{~km}$ ) investigation in the Congo-Angola margins (Equatorial West African margin, 3150-4800 $\mathrm{m}$ ) in which we examined the metazoan meiofauna at a variety of habitats along the Congo Channel system and in the associated cold seep. We investigate the structure, density, vertical distribution patterns in the sediment and biomass of meiofaunal communities in the Gulf of Guinea and how they are controlled by hydrologic and biogeochemical processes. The meiofaunal communities in the Gulf of Guinea were shaped by heterogeneous conditions on the margin, and reflect the multiple-scale spatial variability that corresponds with the different identified habitats. The two control sites, located at $>100 \mathrm{~km}$ away from the canyon, were inhabited by very dense and the most diverse meiobenthic communities. Similar meiobenthic communities inhabited the transition zone between the canyon and the cold seep. Sites located along the Congo Channel were obviously affected by the local high-velocity bottom currents and unstable sedimentary conditions in this active submarine system. Extremely low meiobenthic densities and very low proportions in the most surficial sediment layers provided evidence for recently highly disturbed sediments at these sites. The remote operated vehicle (ROV) Victor 6000 provided images of the cold seep, showing a patchy distribution of several types of patchy distributed megafaunal communities dominated by three key symbiotic taxa (Mytilidae, Vesicomyidae and Siboglinidae). These cold seep sediments were colonised by a unique meiobenthic community, characterised by a high small-scale (m's) patchiness, low species richness and the prominent dominance of two large-sized nematode species: Sabatieria mortenseni, which is a cosmopolitan nematode known from littoral habitats, and an undescribed Desmodora species. The high individual body weight of $S$. mortenseni and its dominance at the cold seep site resulted in a significantly higher nematode biomass at the seep compared to the surrounding sites. In addition, the vertical nematode profiles, with maximum proportions in subsurficial layers, points to a chemosynthesis-based meiobenthic community in this cold seep, in contrast to the phytodetritus-based communities at the control sites and at the transition zone.
\end{abstract}

Keywords: West equatorial Africa margin deep-sea; Congo canyon; Cold seep; Meiofauna; Nematodes; Gulf of Guinea 


\section{Introduction}

Most studies documenting metazoan communities from deep-water cold seeps describe a fauna characterised by an impoverished species richness, elevated dominance and high biomass compared to more common bathyal environments (Buck and Barry, 1998; Olu et al., 1997; Robinson et al., 2004; Levin, 2005). Mega- and macrofaunal seep communities are relatively well described from a wide number of seep locations from different margins (Sibuet and Olu, 1998; Sibuet and Olu, 2002; Levin, 2005). Megafaunal communities consist of high densities of siboglinid tubeworms (Annelida), mytilid, vesicomyid and lucinid bivalves. It has been shown that the distribution of these chemosynthetic species may be regulated by geology, including the geometry of seeps, pattern and intensity of fluid flows and the occurrence of hydrates (Olu-Le Roy et al., 2007). However, studies on seep meiofauna from the deepsea are few and have often been restricted to bulk measurement of abundance and biomass of major taxa (e.g., Powell et al., 1986; Olu et al., 1997; Robinson et al., 2004; Soltwedel et al., 2005a). Only four meiofaunal studies at seeps, including two from deeper water (Shirayama and Ohta, 1990; Jensen et al., 1992; Dando et al., 1991; Van Gaever et al., 2006), provided also information at the genus or species level.

Active cold seeps occur on geologically active and passive continental margins in all oceans of the world, including the polar regions both Arctic and Antarctic (Domack et al., 2005; Levin, 2005). The first seep community described in the South East Atlantic was discovered in 1998 on a giant pockmark along the Equatorial African margin at $3150 \mathrm{~m}$ water depth (Ondréas et al., 2005). Submarine pockmarks are crater-like depressions that are typically wide (10-800 $\mathrm{m}$ in diameter), shallow (up to $45 \mathrm{~m}$ deep) features, occurring in most seas, oceans and in many diverse geological settings (Hovland et al., 2002). Pockmarks occur as discrete features, or as coalescing structures forming extensive pockmark fields up to 1000 $\mathrm{km}^{2}$ (Kelley et al., 1994). They occur wherever some form of fluid and/or gas discharge is focused. Biogenic pockmark fluids originate from the production of methanogenic bacteria (biogenic gas) inside the sediments, from where it migrates to the seafloor entrained in pore water (Kelley et al., 1994). Hydrocarbon pockmark gas is produced by the thermal alteration of sedimentary organic matter (Hovland and Judd, 1988).

Deep-sea canyons are of particular interest for the study of biogeochemical processes as they often act as major path ways for particle-loaded, near-bottom currents transporting material from the continent to the open ocean. Enhanced particle transport along canyons implies an effective food supply to benthic organisms, resulting in higher faunal densities and biomass (Rowe et al., 1982; Soltwedel et al., 2005b). However, some submarine canyons are very unstable environments due to tidal currents and periodic turbidity flows into the system (Puig et al., 2004). Benthic communities often reflect the unstable and organically enriched conditions of these canyon systems. Indeed, macrofaunal communities of canyons exhibit higher densities and biomasses and lower diversities than the communities inhabiting the adjacent abyssal plains, continental shelf and slopes (e.g., Gage et al., 1995; Vetter and Dayton, 1998). The meiofauna of submarine canyons has been rarely studied, and densities are very variable. High fluctuations in the meiobenthic densities were observed in the Nazaré Canyon. This was not only explained by the impact of physical factors, but also by a very strong seasonality in fluvial input (Garciá et al., 2007).

During the multidisciplinary BIOZAIRE 3 cruise (December-January 2003-2004) to the Gulf of Guinea, samples were collected from the passive continental margin of West Africa in the Congo Channel system and adjacent sites. The Congo deep-sea fan is one of the world's largest active submarine canyons, extending $760 \mathrm{~km}$ from the river mouth to the abyssal plain $(>5100 \mathrm{~m})$, downslope from the Congo-Angola continental shelf and covering an estimated area of $330,000 \mathrm{~km}^{2}$. One of the particular characteristics of the Congo Channel system is the permanent connection between the river mouth and the abyssal plain, and this explains why this fan is still active during current high sea level (Khripounoff et al., 2003). Dense chemosynthetic communities have been discovered in a deep isolated pockmark, located at less than $8 \mathrm{~km}$ north of the Congo Canyon. The large size of the pockmark, 800- 
$1000 \mathrm{~m}$ in diameter, is due to the collapse of several individual pockmarks gathered in a pockmark cluster (Charlou et al., 2004; Olu-Le Roy et al., 2007). This giant pockmark, called REGAB, and its surroundings were explored in detail by the remote operated vehicle (ROV) Victor 6000 as part of the ZAIANGO (1998-2000) and BIOZAIRE projects (2001-2003) carried out conjointly by the oil company TOTAL and a number of French research institutes. The BIOZAIRE 3 cruise aimed at understanding the dynamics of the energy inputs, their origins and their consequences for the development of the benthic fauna in four different environments. The present study highlights the density, diversity and biomass of metazoan meiofauna in different sites and habitats along the Congo Channel system and within the REGAB cold seep in the Gulf of Guinea (Equatorial West African margin, $3150 \mathrm{~m}$ ). The following questions were addressed: (1) Do the meiofaunal composition, density and biomass vary on a macroscale $(>100 \mathrm{~km})$ and mesoscale $(5-20 \mathrm{~km})$ in the Gulf of Guinea and is there biological patchiness on a microscale ( $\mathrm{m}$ 's) within the seep? (2) To what extent are the communities similar to other communities from similar environments worldwide and can we relate the observed biological patchiness to particular habitat characteristics?

\section{Material and methods}

\subsection{Study area}

The Congo River is the second largest river in terms of water discharge $\left(40.8 \mathrm{~m}^{3} \mathrm{~s}^{-1}\right)$ and has a strong link with the deep-sea sediments. Frequent turbidity currents carry huge amounts of material down to the abyssal plain up to several tens of kilometres outside the submarine channel system and are suspected to sustain the particular ecosystem on the abyssal plains in the Gulf of Guinea. The finest particles of the upper part of the turbidity currents are even able to overflow the canyon flanks, but these phenomena might not occur at each turbidity event. The organic matter of the turbiditic overflow has a strong terrigenous signal, and its influence is visible in the total organic carbon content as well as in the $n$-alcohol composition (Treignier et al., 2006; Treignier et al., this volume).

The Congo Canyon represents a very active submarine system, as two major turbidity events with speeds of up to $97-120 \mathrm{~cm} \mathrm{~s}^{-1}$ at $150 \mathrm{~m}$ above the channel floor were reported from March 2001 and January 2004. The current speed close to the channel bottom would have been even higher as the flow had enough energy to transport a large quantity of sand and large plant remains. Smaller, local turbidity events without any speed accelerations are suspected to arrive frequently (Khripounoff et al., 2003; Vangriesheim et al., this volume).

The REGAB cold seep in the Gulf of Guinea is located at an average depth of $3150 \mathrm{~m}$, on the oceanic crust $<8 \mathrm{~km}$ north of the Congo Canyon, (Fig. 1). This 800-m wide, 15-20 m deep pockmark appears to be formed by the association of several individual pockmarks, resulting in a large area covered by a dense chemosynthetic community. Photographs taken with the ROV Victor 6000 illustrate seepages of methane, gas hydrates, carbonate crusts, and a very patchy distribution of faunal assemblages, either dominated by bivalves of the families Mytilidae (Bathymodiolus sp.) or Vesicomyidae (Calyptogena sp.), or by siboglinid tubeworms (Escarpia southwardae, Andersen et al., 2004). The distribution of these symbiont-bearing megafauna is controlled by the substrate and the present methane concentrations in seawater. In this chemosynthetic environment, increased macrofaunal densities with higher spatial fluctuations were found in comparison to the background sediments (Olu-Le Roy et al., 2007).

\subsection{Sampling strategy}

Meiofaunal sediment samples were collected in the Gulf of Guinea by the French RV Atalante during the cruises BIOZAIRE 2 in November-December 2001 and BIOZAIRE 3 in December-January 2003-2004. The cold seep REGAB which was directly under the effect 
of methane emission (Treignier et al., 2006; Treignier et al., this volume), was sampled with push cores of the ROV Victor 6000 (surface of $21.2 \mathrm{~cm}^{2}$ ), while all other sites were sampled with a multiple corer (tube surface of $30.2 \mathrm{~cm}^{2}$ ) (Fig. 1 and Fig. 2, Table 1).

Two samples (V1, V3) of the REGAB cold seep were taken at a patch densely colonised by clams (Vesicomyidae) and three samples (M1, M2, M3) at a patch dominated by mussels (Mytilidae) (Fig. 2).

Furthermore three adjacent sites (R3 at $3174 \mathrm{~m}, \mathrm{R} 4$ at $3167 \mathrm{~m}, \mathrm{R} 6$ at $3163 \mathrm{~m}$ ) were sampled at the transition zone located at the southern edge of this cold seep in a zone influenced by the Congo Channel system (Fig. 2).

Along the Congo Channel system three sites were sampled: one at the abyssal plain (Lobe at $4788 \mathrm{~m}$ ), one at the channel bottom (Channel at $4067 \mathrm{~m}$ ) and one $13 \mathrm{~km}$ south of the canyon (Levee at $3964 \mathrm{~m}$ ). Finally also two control sites (A at $1304 \mathrm{~m}, \mathrm{C}$ at $3994 \mathrm{~m}$ ) mainly dependent on plankton input, were sampled far away (150-200 km) from the canyon (Fig. 1). At each site, two replicate cores were sampled.

The sediment of each core was sectioned horizontally in 1-cm layers down to $5 \mathrm{~cm}$ sediment depth. If collected, the following 5-cm slice was taken as one bulk sample. All sediment slices were fixed in $4 \%$ buffered formaldehyde and washed over a $32 \mu \mathrm{m}$-mesh sieve. Metazoan meiofaunal organisms were extracted from the sediment by centrifugation with Ludox, and stained with Rose Bengal. Afterwards the meiofauna was sorted out, enumerated and identified to major taxa under the stereomicroscope. From each slice, 100 nematodes were picked out at random, mounted in glycerine slides and identified to genus level.

Body length $(L, \mu \mathrm{m})$ (excluding filiform tails) and maximal body width $(\mathrm{W}, \mu \mathrm{m})$ of 100 nematodes were measured in order to estimate the dry weight (DW). Individual biomasses were calculated from Andrassy's (1956) formula for wet body weight (WW). A specific nematode gravity of $1.13 \mathrm{~g} \mathrm{~cm}^{-3}$ and a dry-to-wet weight ratio of 0.25 were assumed (Wieser, 1960).

Sediments from each site (except the cold seep) were subjected to granulometric analysis by means of a Coulter counter LS 100.

\subsection{Statistics}

The STATISTICA6 software was used to perform parametric and non-parametric analyses. Bartlett's and Cochran's test were used to verify the homogeneity of variances prior to the analysis. Parametric (one-way ANOVA) analysis on log-transformed data was used to compare total nematode and individual nematode biomass of the different sites along the Congo Channel. Non-parametric analysis (Kruskal-Wallis ANOVA by ranks) was carried out to describe differences in total meiobenthic densities.

Non-metric multidimensional scaling (MDS, PRIMER v5.0 statistical package from the Plymouth Marine Laboratory) was applied in order to visualize the dissimilarity among sites with respect to nematode genus composition. A first MDS was made using the data of all sites, while in the second MDS only the group of control, levee and transition sites was plotted. The stress value gives a measure for goodness-of-fit of the MDS ordination: a low stress value $(<0.2)$ indicates a good ordination with no real prospect for a misleading interpretation (Clarke, 1993). Both MDS plots had a stress value of 0.08 , indicating that most of the variability present in the data was reduced into the two dimensions of the plot.

\section{Results}

\subsection{Density and diversity of the meiobenthic community}

Average total meiofaunal densities differed significantly among sites (Kruskal-Wallis, $p=$ 0.01) (Fig. 3 and Fig. 4, Table 2). Highest densities were found at the control areas (1005 \pm 78 ind. $10 \mathrm{~cm}^{-2}$ in control site C, $1320 \pm 460$ ind. $10 \mathrm{~cm}^{-2}$ in control site A). No strong 
decrease with water depth was present since meiofaunal densities at $4000 \mathrm{~m}$ were still around 1000 ind. $10 \mathrm{~cm}^{-2}$. The sites along the Congo Channel were characterised by extremely low densities ( $<20$ ind. $10 \mathrm{~cm}^{-2}$ ); except the Levee site which showed intermediary densities (506 \pm 100 ind. $10 \mathrm{~cm}^{-2}$ ). The transition zone between seep and canyon also showed intermediary densities (677-796 ind. $10 \mathrm{~cm}^{-2}$ ) whereas the seep centre showed a high variation in densities from about 870 to less than 20 ind. $10 \mathrm{~cm}^{-2}$.

Diversity at meiobenthic phylum level was high at the control sites and the transition zone with a maximum of 14 different meiobenthic taxa in control site $A$. Lower numbers of meiofaunal taxa were observed at the sites along the canyon and at the seep centre sites, with a minimum of only 2 taxa (nematodes and polychaetes) at the channel bottom. Nematodes were the dominant group at all sites, making up between $49.5-96.5 \%$ of the meiofauna, followed by the copepods and nauplii which reached together a maximum of $8.4 \%$ at control site A (Fig. 3). The samples obtained from the cold seep had lower percentages (0.8-1.2\%) of copepods and nauplii, and these two taxa did not occur at all at the Channel site. In contrast, some other meiobenthic taxa became more abundant at the cold seep: kinorhynchs were strongly concentrated at the sites with clams (up to 15.1\%), while in one of the mussel bed sites (M2), polychaetes accounted for $26.0 \%$ and gastrotrichs for $16.5 \%$ of the associated meiobenthos. Other meiobenthic taxa, including ostracods, bivalves and tanaids, were observed frequently, but in low densities. Tardigrades were only present at the shallowest control site A.

\subsection{Vertical nematode profiles in the sediments}

As nematodes made up the largest fraction of the meiobenthos at all sites, their densities followed the same pattern compared to the total meiobenthic densities, with highest values at the control sites and lowest at the channel bottom (Fig. 3 and Fig. 4).

The control sites showed a gradual decrease in densities from the surface to the deeper layers (Fig. 5). A similar pattern was observed for the canyon levee whereas along the channel system subsurface maxima up to 3 and $5 \mathrm{~cm}$ depth were observed. Also three samples from the seep centre (i.e., M3, V1 and V3) showed subsurface densities maxima at 2 and $3 \mathrm{~cm}$ sediment depth. Away from the centre at the transition zone the nematodes showed a very even vertical distribution pattern down to $4 \mathrm{~cm}$ sediment depth. Only at the furthest transition site (R3) a clear surface maximum similar to the control sites was present.

\subsection{Nematode biomass}

There is a significant increase $\left(F_{6,14}=10.25, p=0.0002\right)$ in individual nematode biomass measured in the samples of the cold seep (0.32-0.94 $\mu \mathrm{g} \mathrm{DW})$; these had up to 9 times higher biomass than the average calculated for the individual nematodes of the other sites $(0.03 \pm 0.01$ to $0.18 \pm 0.20 \mu \mathrm{g} \mathrm{DW})$. This results in significantly higher total nematode biomasses in the two samples from the clam beds $\left(181.45-383.61 \mu \mathrm{g} \mathrm{DW} 10 \mathrm{~cm}^{-2}\right)$ and one sample from a mussel bed (M3 with $792.18 \mu \mathrm{g} \mathrm{DW} 10 \mathrm{~cm}^{-2}$ ) compared to the nematode biomasses from the other sites (ranging between $0.20 \pm 0.20 \mu \mathrm{g} \mathrm{DW} 10 \mathrm{~cm}^{-2}$ in Channel site and $74.97 \pm 15.41 \mu \mathrm{g}$ DW $10 \mathrm{~cm}^{-2}$ in control site C) $\left(F_{6,14}=3.89, p=0.017\right)$ (Fig. 3).

\subsection{Nematode genus diversity}

Nematode communities in both control sites were similar to eachother, although different proportions in the dominant genera were present; Leptolaimus had the highest relative abundance (13.2\%) in site A whereas Microlaimus dominated the deeper site C with 33.6\% (Table 3). These two genera were responsible for the high densities in both control sites. Microlaimus also made up $25.9-35.6 \%$ of the nematode densities at the deeper channel sites. The nematode communities found at the three transition zone sites on the southern 
border of the cold seep were dominated by the genera Thalassomonhystera (up to 17.5\%), Acantholaimus (up to 11.9\%), Microlaimus (up to 10.7\%), Leptolaimus (up to $9.4 \%$ ) and Amphimonhystrella (up to 9.0\%). The samples taken at the Levee site revealed a similar nematode assemblage dominated by Thalassomonhystera (21.5\%) and Acantholaimus (18.4\%). Samples obtained from the cold seep showed a completely different nematode assemblage compared to the other sites. These communities consisted of a very low number of genera (4-14) compared to the control sites (65-82) (Table 4). All seep samples were strongly dominated by Sabatieria mortenseni, and/or dominated by one undescribed Desmodora species. An illustration of the dominant nematode species or genera at the seep site, and at the non-seep sites are shown in Figure 6. As all photographs of the total nematodes were put on the same scale, the significant difference between the mean body size at REGAB seep and the other sites is obvious. The two additional pictures for each nematode are details of morphological structures (amphid, spicule, precloacal supplements) which are necessary to identify them to genus or species level (Fig. 6).

Nematode genus diversity for all sites is shown in Table 4 . The highest values were found at the shallowest control station at $1304 \mathrm{~m}$, while the lowest nematode diversity was present at the cold seep samples and the deeper channel samples (Channel site and Lobe site). Diversity estimates were still high at the transition zone (site R3, R4 and R6), at the Levee site and the deeper control site $\mathrm{C}$.

An MDS based on the nematode genus densities of all samples revealed a clear distinction of the seep and deeper canyon samples, attributed to the high dominance of different species at the seep and very low densities in the canyon (Fig. 7). The upper MDS plot was based only on the group of control, levee and transition sites, and confirmed the gradual differences in nematode community structure among these sites.

\section{Discussion}

\subsection{Deep-sea control sites in the Gulf of Guinea}

Meiofaunal abundances at the control sites were higher by a factor of two or three compared to the regression line of meiofaunal density against water depth based on the study from the continental margins off the western African coast between Guinea $\left(10^{\circ} \mathrm{N}\right)$ and Angola $\left(18^{\circ} \mathrm{S}\right)$ (Soltwedel, 1997) (Fig. 4). Soltwedel (1997) reported low meiofaunal densities at transects sampled off Gabon and the Congo estuary, compared to those at transects located more north and south of this area. The western South Atlantic is characterised by gradients in surface productivity due to spatially and seasonally varying coastal upwelling. It was hypothesised that the identified discrepancies between lower meiofaunal standing stocks and high pigment values may indicate a dislocation of (phyto-) detritus possibly caused by a coastal branch of the Benguela Current and the Congo River outflow (Soltwedel, 1997). Another explanation could have been predator-prey interactions regulating the meiobenthic stock sizes (Soltwedel, 1997), but this can be rejected as maximum macrobenthic densities (702.0 \pm 121.4 ind. $0.25 \mathrm{~cm}^{-2}$, Galéron et al., this volume) were found at the control site C characterised by a dense meiobenthic infauna. The sediment at both control sites was well oxygenated (>35 mm at site C) (J.C. Caprais, personal communication). Particulate matter input originating from the water-column primary productivity (Rabouille et al., this volume) and concentrations of $n$-alcohols considered as biomarkers of pelagic and terrestrial origin of particles were measured at control site C (Treignier et al., 2006). This station revealed the highest short/long ratio (6.4) of $n$-alcohols, which is indicative of a major marine plankton input (Treignier et al., 2006; Treignier et al., this volume). However, the value suggests that control site $\mathrm{C}$ is likely to receive terrestrial material. Previous studies indicated that the influence of the Congo River plume extends over an extensive area and even reaches the deepest control site. The high meiobenthic densities at the control sites of the Gulf of Guinea could be explained by the frequent input of food originating from pelagic resources 
(phytoplankton, zooplankton and bacteria) (Treignier et al., 2006). The sediments of the deepest control station $\mathrm{C}$ were characterised by exceptionally high relative abundances of Microlaimus. This nematode genus is known to be opportunistic, and is often found to be dominant or subdominant in areas with an increased organic input such as on the Darwin Mounds (Rockall Trough, north-east Atlantic) (Van Gaever et al., 2004) and the Siboglinidae fields of the Håkon Mosby Mud Volcano (SW Barents Sea slope) (Van Gaever et al., 2006). Vertical nematode distributions with highest relative abundances in the most surficial layers in both control sites pointed to a surface-derived food supply for the endobenthos.

\subsection{Transect in transition zone between Congo Canyon and cold seep}

In the transition zone at the southern edge of the REGAB seep, densities were slightly lower than at the control station $\mathrm{C}$ at a similar depth, but still twice as high as predicted by the regression for the continental margins off the western African coast (Soltwedel, 1997). Nematode diversity appeared to be also slightly lower than at the control station $C$, and typical deep-sea genera dominated these communities: Thalassomonhystera, Acantholaimus, Microlaimus, Leptolaimus and Amphimonhystrella. The vertical profiles of the nematode abundance in the sediment showed a gradual change from the seep towards the canyon; there was a more even distribution with the highest proportion of nematodes in the layer $2-3 \mathrm{~cm}$ close to the seep to a more typical deep-sea vertical profile with the maximum nematode proportion in the surface layer further from the seep.

\subsection{Sites along and influenced by the Congo Channel system}

Data on meiobenthic densities of submarine canyon channel systems are sparse but highly variable. Meiofaunal densities of ca. 1000 ind. $10 \mathrm{~cm}^{-2}$ were reported from the Ardencaple Canyon (Western Greenland Sea; Soltwedel et al. 2005b), in the Monterey Canyon off northern California (Carman et al., 2004) and in the Alaminos Canyon (Gulf of Mexico; Baguley et al., 2006), while Robinson et al. (2004) observed very low meiofaunal densities $\left(<90\right.$ ind. $\left.10 \mathrm{~cm}^{-2}\right)$ at seeps in Alaminos Canyon. Also the meiobenthic communities inhabiting the sediments of the Nazaré Canyon were subjected to high fluctuations in density (18-1387 ind. $10 \mathrm{~cm}^{-2}$ ) due to periodic bottom currents and a strong impact of seasonality (Garciá et al., 2007).

Extremely low meiofaunal densities, diversity and biomass were found at the deeper sites along the Congo Channel system, and the highest nematode proportions were present in the subsurficial layers. The nematode genus Microlaimus made up a very important fraction of the community at these Channel sites. This genus was also dominant during the recolonisation of shallow Antarctic sediments after a catastrophic iceberg scouring and seems to be able to withstand great sedimentary disturbance. This scouring disturbance led to a certain degree of reduction in diversity and a notable decrease in meiofaunal abundance $(>95 \%)$ which was outside the range of seasonal fluctuation, even considering the patchy distribution of nematodes as described in a previous study on temporal variation (Vanhove et al., 2000). The pioneering meiofaunal colonisers after the iceberg scouring were copepods and ostracods, followed by nematodes with a Microlaimus sp. as dominant species throughout the whole period (Lee et al., 2001). The almost complete absence of a meiobenthic community and the high relative abundance of Microlaimus at the deeper Congo Channel sites from this study are possibly controlled by the current activity in the Congo submarine valley, and the additional very weak oxygen penetration of $7 \mathrm{~mm}$ at the Channel site and only $2-3 \mathrm{~mm}$ at the Lobe site (J.C. Caprais, personal communication). All other sites were well oxygenated up to 23-39 $\mathrm{mm}$ in the sediment (J.C. Caprais, personal communication). Periodic turbidity events occur frequently in the Congo Canyon (Khripounoff et al., 2003), and may cause resuspension and transport of the surface sediments down to the abyssal plain, leading to unstable sediment substrate. Moreover, high sedimentation rates may lead to fauna being buried by sediment. According to Treignier et al. (this volume), 
there is a high input of terrestrial, organic matter, but apparently large turbidity events prevent the establishment of meiofauna communities. Higher predation pressure on the nematodes could be another explanation of the extremely low meiobenthic densities and subsurface maxima in the Channel and Lobe site. Unfortunately, no macro- or megafaunal data of these sites were available to check this hypothesis. The sediments at the Levee site located at $13 \mathrm{~km}$ south from the Congo Canyon were oxygenated up to $39 \mathrm{~mm}$ sediment depth (J.C. Caprais, personal communication) and likely to be less exposed to turbidity flows compared to the sites inside the channel system. Meiofaunal densities, nematode diversity, dominant nematode genera and vertical nematode distribution at the Levee site were very similar to those at the transition zone. Although an overflow onto the levees occurred in 2001, the increase of organic matter at the surface which was observed up to 9 months after the event, disappeared after two years (Khripounoff et al., 2003). The sedimentation of terrestrial organic matter in this site depends on the frequency of the overflows, which is linked to their thickness and expansion (Treignier et al., this volume).

\subsection{Giant pockmark complex REGAB}

A completely different meiobenthic community was present at the cold seep REGAB. Highest meiofaunal densities were similar to those at the transition zone, although the seep samples were characterised by a very high variability in density and exhibited low nematode diversity. Kinorhynchs and polychaetes also showed a very patchy distribution. A maximum of only 14 nematode genera was found in this site, and two dominant nematode species (Sabatieria mortenseni and Desmodora sp., Fig. 6) made up on average more than $70 \%$ of the total nematode densities. The very large individual biomass of Sabatieria mortenseni resulted in a significantly higher biomass in the two samples from the clam bed and one sample from a mussel bed.

Sabatieria is one of the dominant genera in muddy, reduced sediments of shallow water sites all over the world (Warwick and Gee, 1984; Vincx, 1986; Jensen, 1987; Ott et al., 1991; Polz et al., 1992; Soetaert and Heip, 1995), and many of its species are considered eurytopic and tolerant of unstable, highly polluted environments (Jensen, 1984; Vanreusel, 1990; Steyaert et al., 1999). The genus can attain high proportions at oxygen minima along the slope but gradually disappears almost completely in sediments deeper than $2000 \mathrm{~m}$ (Soetaert and Heip, 1995; Vanaverbeke et al., 1997). Sabatieria mortenseni is a cosmopolitan that is already reported from littoral sediments with a high amount of clay and mud in Brazil, USA, Antarctica (Ditlevsen, 1921; Allgén, 1947; Allgén, 1959; Pastor de Ward, 1984) and in the Strait of Magellan (Chile) in a depth range of 8-550 m (Chen, 1999). The observation of a dominant species in the reduced seep sediments known from shallow waters with a wide distribution is similar to the dominant nematode from the sulphide-rich sediments at Håkon Mosby Mud Volcano (Halomonhystera disjuncta) (Van Gaever et al., 2006).

The genus Desmodora is present in most of the assemblages studied in deep-sea sediments, but always at low densities (relative abundance is a maximum of $1 \%$ of the total community). Some species of Desmodora were described from hydrothermal vents of the Pacific (Verschelde et al., 1998). Bernhard et al. (2000) reported the presence of the ectosymbiont-harbouring Desmodora masira in the oxygen minimum zone of the Santa Barbara Basin (California margin, 475-600 m). The species observed at the REGAB seep has not been described.

Metazoan meiofaunal assemblages within seeps often show large variations in densities and highly patchy distributions. At a mud volcano in the northern Barbados prism densities ranged between 116 and 11364 ind. $10 \mathrm{~cm}^{-2}$ across different seep sub-habitats (Olu et al., 1997). The metazoan meiobenthic communities present at Håkon Mosby Mud Volcano (HMMV) in the Eastern Atlantic were characterised by similar highly significant differences (513-11 292 ind. $10 \mathrm{~cm}^{-2}$ ) among sub-habitats (Van Gaever et al., 2006). The most surprising result were the unusually high densities of a single nematode species 
Halomonhystera disjuncta associated with the sulphidic sediments underneath the microbial mats and thriving on chemosynthetically derived food sources (Van Gaever et al., 2006).

Meiofaunal abundances within the REGAB seep varied between 20 ind. $10 \mathrm{~cm}^{-2}$ and 873 ind. $10 \mathrm{~cm}^{-2}$. The small-scale heterogeneity in methane levels is hypothesised to have an important influence both on the megafaunal and meiofaunal patchiness at this seep site. The meiofaunal assemblages at the seep were strongly dominated by two nematode species (Sabatieria mortenseni and Desmodora sp.) which disappeared completely in samples collected outside the seep. These species did not reach extremely high densities, but were characterised by a very large individual biomass, resulting in a maximum total nematode biomass at the mussel bed at REGAB similar to the maximum total biomass made up by the abundant Halomonhystera disjunta at HMMV (Van Gaever et al., 2006).

The increased nematode biomass and subsurface distribution maxima suggest that this unique meiobenthic community at REGAB is based on chemosynthesis, in contrast to the phytodetritus-based assemblages found at the control sites and the transition zone. There was no clear evidence of endosymbionts in the seep nematodes, but it is possible that these nematodes benefit from free-living chemoautotrophic bacteria as food source. Obviously, the diversity and density patterns of the meiofauna indicate that these cold seep communities are strongly controlled by the patchy biogeochemical sediment conditions such as variable levels of oxygen, sulphide and methane.

\section{Conclusions}

Distinct meiofaunal communities could be distinguished, reflecting a multiple-scale (from m's to $200 \mathrm{~km}$ ) spatial variability that corresponds with the different habitats in the Gulf of Guinea. Apparantly, nematode abundances could be as different on a microscale ( $m$ 's) in the cold seep as they were on larger spatial scales (tens of $\mathrm{km}$ ). Nematode assemblage composition exhibited more consistent patterns within a smaller area, but was also highly variable if different habitats on a mesoscale and macroscale were compared.

Studies of the total metazoan meiofauna community and on the nematode genus level can yield important information concerning habitat characteristics in the deepsea. Increasing nematode densities and biomass often points out the presence of an abundant food resource and/or high food quality. The use of chemosynthesis in reduced sediments can result in significant higher nematode biomasses. The proliferation of some nematode 'indicator' genera helps to identify environmental conditions.

For instance, the genus Sabatieria is well adapted to living in fine-sediment and reduced sediments. This nematode is an indicator for anoxic to sub-oxic sediments and will be successful in those environments where a substantial fraction of organic matter becomes incorporated below the oxic zone in the sediment, or in sediments where it can benefit from chemosynthetic nutritional path ways. Sabatieria mortenseni was observed to be very dominant in the seep samples from this study. Apparently, dominant nematodes from these isolated habitats are often cosmopolitan eurybathic species with very high tolerance levels. Similar trends were found for Foraminifera, where no seep endemics have been identified and most seep genera were also characteristic of other low oxygen, organic rich settings (Bernhard et al., 2001; Rathburn et al., 2000, 2003). The high resistance of these meiofaunal species permits them to successfully colonise a specific niche in these marine sediments, often with toxic conditions. However, molecular studies on nematodes indicate that cryptic species specialisation is likely to be substantial within marine free-living nematodes, as shown for the species Halomonhystera disjuncta (Derycke et al., 2007).

Microlaimus may constitute a successful opportunistic coloniser in recently disturbed and organically enriched sediments and can exploit different types of substrate. Frequently occurring turbidity events in the Congo Channel prevent the establishment of a stabile meiofaunal community and result in extremely low densities in the channel system. The 
conditions in the canyon are harsh, as only opportunistic and good colonisers like Microlaimus species are found albeit in low densities.

In general, both the physical (strong bottom currents in channel system), the fluctuating sedimentary biogeochemical conditions (in particular at the seep site), as well as the food supply from the continental shelf are reflected in the densities and diversity patterns of the meiobenthos at the different deep-sea habitats in the Gulf of Guinea. The extended knowledge of nematode diversity and density patterns in the deepsea provide essential information on habitat preference. Biogeochemical variables of the sediment (such as oxygen, methane, sulphide, $\mathrm{pH}$, etc.) as well as environmental conditions of the surrounding area on a small scale (organic content, macrofaunal communities, etc.) and even on a larger scale (water depth, topographic submarine structures, water bottom currents) all have an impact on the community structure of marine nematodes. Moreover, because marine nematodes are distributed worldwide, are the most prominent members of the smaller-sized animals, and have a direct link with the sediment and with the processes that occur immediately above the sediments, this group can be utilised as an interesting tool to describe and identify habitat heterogeneity in the marine environment.

\section{Acknowledgements}

The BIOZAIRE cruises were organised in the framework of a collaboration between Ifremer and the oil company TOTAL. We thank the officers and the crew of the RV l'Atalante and all scientific participants for their work and support during the sampling campaign BIOZAIRE 3. We are also grateful to D. Schram for the sediment measurements, and to M.-C. Fabri and K. Olu-Le Roy for the illustrative maps of the study area. This research was supported by Ghent University and the FWO project 'Cold Seeps' nr. G034607. This publication is contribution number MPS-08014 of MarBEF (Marine Biodiversity and Ecosystem Functioning).

\section{References}

Allgén, C.A., 1947. West American Marine Nematodes (Papers from Dr. Th. Mortensen's Pacific Expedition 1914-16. LXXV) Videnskabelige Meddeleser fra Dansk Naturhistorisk Forening 110, 65-219.

Allgén, C.A., 1959. Freeliving marine nematodes. Further Zoological Results of the Swedish Antarctic Expedition 1901-1903. Stockholm, 5(2), 1-293.

Andersen, A.C., Hourdez, S., Marie, B., Jollivet, D., Lallier, F.H., Sibuet, M., 2004. Escarpia southwardae sp nov., a new species of vestimentiferan tubeworm (Annelida, Siboglinidae) from West African cold seeps. Canadian Journal of Zoology-Revue Canadienne de Zoologie 82(6), 980-999.

Andrassy, I., 1956. The determination of volume and weight of nematodes. Acta Zoologica Academiae Scientiarum Hungaricae 2, 1-15.

Baguley, J.G., Montagna, P.A., Hyde, L.J., Kalke, R.D., Rowe, G.T., 2006. Metazoan meiofauna abundance in relation to environmental variables in the northern Gulf of Mexico deep sea. Deep-Sea Research I 53, 1344-1362.

Bernhard, J.M., Buck, K.R., Farmer, M.A., Bowser, S.S., 2000. The Santa Barbara Basin is a symbiosis oasis. Nature 403, 77-80.

Bernhard, J.M., Buck, K.R., Barry, J.P., 2001. Monterey Bay cold-seep biota: assemblages, abundance, and ultrastructure of living foraminifera. Deep-Sea Research I 48, 2233-2249.

Buck, K.R., Barry, J.P., 1998. Monterey Bay cold seep infauna: quantitative comparison of bacterial mat meiofauna with non-seep control sites. Cahiers de Biologie Marine 39, 333335. 
Carman, K.R., Thistle, D., Fleeger, J.W., Barry, J.P., 2004. Influence of introduced $\mathrm{CO}_{2}$ on deep-sea metazoan meiofauna. Journal of Oceanography 60, 767-772.

Charlou, J.L., Donval, J.P., Fouquet, Y., Ondreas, H., Knoery, J., Cochonat, P., Levaché, D., Poirier, Y., Jean-Baptiste, P., Fourré, E., Chazallon, B., The ZAIROV Leg 2 Scientific Party, 2004. Physical and chemical characterisation of gas hydrated and associated methane plumes in the Congo-Angola Basin. Chemical Geology 205, 405-425.

Chen, G., 1999. Ecology and systematics of the meiofauna and nematode communities in the Strait of Magellan and the Beagle Channel (Chile). Ph.D. Thesis, Ghent University, Ghent, Belgium, unpublished.

Clarke, K.R., 1993. Non-parametric multivariate analysis of changes in community structure. Australian Journal of Ecology 18, 117-143.

Dando, P.R., Austen, M.C., Burke, R.A., Kendall, M.A., Kennicutt, M.C., Judd, A.G., Moore, D.C., Ohara, S.C.M., Schmaljohann, R., Southward, A.J. 1991. Ecology of a North Sea pockmark with an active methane seep. Marine Ecology Progress Series 70, 49-63.

Derycke, S., Backeljau, T., Vlaeminck, C., Vierstraete, A., Vanfleteren, J., Vincx, M., Moens, T., 2007. Spatiaotemporal analysis of population genetic structure in Geomonhystera disjuncta (Nematoda, Monhysteridae) reveals high levels of molecular diversity. Marine Biology 151, 1799-1812.

Ditlevsen, H., 1921. Papers form Dr. Th. Mortensen's Expedition 1914-16. III. Marine freeliving nematodes from the Auckland and Campbell Islands. Videnskabelige Meddeleser fra Dansk Naturhistorisk Forening Kjobenhavn 73, 1-32.

Domack, E., Ishman, S., Leventer, A., Sylva, S. Willmott, V., Huber, B., 2005. A chemotrophic ecosystem found beneath Antarctic ice shelf. EOS: Transactions, American Geophysical Union 86, 269 and 271-272.

Gage, J.D., Lamont, P.A., Tyler, P.A., 1995. Deep-sea macrobenthic communities at contrasting sites off Portugal, Preliminary Results. 1. Introduction and diversity comparisons. Internationale Revue der Gesamten Hydrobiologie 80, 235-250.

Garciá, R., Koho, K.A., De Stigter, H.C., Epping, E., Koning, E., Thomsen, L., 2007. Distribution of meiobenthos in the Nazaré canyon and adjacent slope (western Iberian Margin) in relation to sedimentary composition. Marine Ecology Progress Series 340, 207220.

Hovland, M., Judd, A.G., 1988. Seabed Pockmarks and Seepages. Graham and Trotman, London.

Hovland , M., Gardner, J.V., Judd, A.G., 2002. The significance of pockmarks to understanding fluid flow processes and geohazards. Geofluids 2, 127-136.

Jensen, P., 1984. Ecology of benthic and epiphytic nematodes in brackish waters. Hydrobiologia 108, 201-217.

Jensen, P., 1987. Differences in microhabitat, abundance, biomass and body size between oxybiotic and thiobiotic free-living marine nematodes. Oecologia 71, 564-567.

Jensen, P., Aagaard, I., Burke, R.A., Dando, P., Jorgensen, N.O., Kuijpers, A., Laier, T., Ohara, S.C.M., Schmaljohann, R., 1992. 'Bubbling reefs' in the Kattegat - submarine landscapes of carbonate-cemented rocks support a diverse ecosystem at methane seeps. Marine Ecology Progress Series 83, 103-112.

Kelley, J.T., Dickson, S.M., Belknap, D.F., Barnhardt, W.A., Henderson, M., 1994. Giant seabed pockmarks: evidence for gas escape from Belfast Bay, Maine. Geology 22, 59-62.

Khripounoff, A., Vangriesheim, A., Babonneau, N., Crassous, P., Dennielou, B., Savoye, B., 2003. Direct observation of intense turbidity current activity in the Zaire submarine valley at 4000 m water depth. Marine Geology 194, 151-158.

Lee, H.J., Vanhove, S., Peck, L.S., Vincx, M., 2001. Recolonisation of meiofauna after catastrophic iceberg scouring in shallow Antarctic sediments. Polar Biology 24, 918-925.

Levin, L.A., 2005. Ecology of cold seep sediments: interactions of fauna with flow, chemistry and microbes. Oceanography and Marine Biology 43, 1-46.

Olu, K., Lance, S., Sibuet, M., Hendry, P., Fiala-Dedioni, A., Dinet, A., 1997. Cold seep communities as indicators of fluid expulsion patterns through mud volcanoes seaward of the Barbados Accretionary Prism. Deep-Sea Research I 44, 811-841. 
Olu-Le Roy, K., Caprais, J.-C., Fifis, A., Fabri, M.-C., Galéron, J., Budzinsky, H., Le Ménach, K., Khripounoff, A., Ondréas, H., Sibuet, M., 2007. Cold-seep assemblages on a giant pockmark off West Africa: spatial patterns and environmental control. Marine Ecology 27, 116.

Ondréas, H., Olu, K., Fouquet, Y., Charlou, J.L., Gay, A., Dennielou, B., Donval, J.P., Fifis, A., Nadalig, T., Cochonat, P., Cauquil, E., Bourillet, J.F., Le Moigne, M., Sibuet, M., 2005. ROV study of a giant pockmark on the Gabon continental margin. Geo-Marine Letters 25, 281-292.

Ott, J.A., Novak, R., Schiemer, F., Hentschel, U., Nebelsick, M., Polz, M., 1991. Tackling the sulfide gradient: a noval strategy involving marine nematodes and chemoautotrophic ectosymbionts. PSZNI Marine Ecology 12, 261-279.

Pastor de Ward, C.T., 1984. Nematodes marinos de la ria Deseado (Axonolaimoidea: Axonolaimidae, Diplopeltidae, Comesomatidae) Santa Cruz, Argentina. 4. Centro Nacional Patagónico Contribucion 86, 1-21.

Polz, M.F., Felbeck, H., Novak, R., Nebelsick, M., Ott, J.A., 1992. Chemoautotrophic, sulphur-oxidizing symbiotic bacteria on marine nematodes: morphological and biochemical characterization. Microbial Ecology 24, 313-329.

Powell, E.N., Bright, T.J., Brooks, J.M., 1986. The effect of sulphide and an increased foodsupply on the meiofauna and macrofauna at the east-flower-garden brine seep. Helgoländer Meeresuntersuchungen 40, 57-82.

Puig, P., Ogston, A.S., Mullenbach, B.L., Nittrouer, C.A., Parson, J.D. Sternberg, R.W., 2004. Storm-induced sediment gravity flows at the head of the Eel submarine canyon, northern California margin. Journal of Geophysical Research 109, C03019, doi:10.1029/2003JC001918.

Rathburn, A.E., Levin, L.A., Held, Z.A., Lohmann, K.C., 2000. Benthic foraminifera associated with cold methane seeps on the Northern Californian margin: ecology and stable isotopic composition. Marine Micropaleontology 38, 247-266.

Rathburn, A.E., Perez, M.E., Martin, J.B., Day, S.A., Mahn, C., Gieskes, J., Ziebis, W., Williams, D., Bahls, A., 2003. Relationship between the distribution and stable isotopic composition of living benthic foraminifera and cold methane seep biogeochemistry in Monterey Bay, California. Geochemistry Geophysics Geosystems 4, 1106.

Robinson, C.A., Bernhard, J.M., Levin, L.A., Mendoza, G.F., Blanks, J.K., 2004. Surficial hydrocarbon seep infauna from the Blake Ridge (Atlantic Ocean, $2150 \mathrm{~m}$ ) and the Gulf of Mexico (690-2240m). P.S.Z.N.: Marine Ecology 25, 313-336.

Rowe, G.T., Polloni, P.T., Haedrich, R.L., 1982. The deep-sea macrobenthos on the continental margin of the northwest Atlantic Ocean. Deep-Sea Research 29, 257-278.

Shirayama, Y., Ohta, S., 1990. Meiofauna in a cold-seep communitiy off Hatsushima, Central Japan. Journal of the Oceanographical Society of Japan 46, 118-124.

Sibuet, M., Olu, K., 1998. Biogeography, biodiversity and fluid dependence of deep-sea coldseep communities at active and passive margins. Deep-Sea Research II 45, 517-567.

Sibuet, M., Olu-Le Roy, K., 2002. Cold seep communities on continental margins: structure and quantitative distribution relative to geological and fluid venting patterns. In: Wefer, G., Billett, D., Hebbeln, D., Jørgensen, B.B., Schlüter, M., Van Weering, T. (Eds.), Ocean Margin Systems. Springer-Verlag Berlin Heidelberg, pp. 235-251.

Soetaert, K., Heip, C., 1995. Nematode assemblages of deep-sea and shelf break sites in the North-Atlantic and Mediterranean Sea. Marine Ecology Progress Series 125, 171-183.

Soltwedel, T., 1997. Meiobenthos distribution pattern in the tropical East Atlantic: indication for fractionated sedimentation of organic matter to the sea floor? Marine Biology 129, 747756.

Soltwedel, T., Hasemann, C., Quéric, N.-V., von Juterzenka, K., 2005a. Gradients in activity and biomass of the small benthic biota along a channel system in the deep Western Greenland Sea. Deep-Sea Research I 52, 815-835.

Soltwedel, T., Portnova, D., Kolar, I., Mokievsky, V., Schewe, I., 2005b. The small-sized benthic biota of the Håkon Mosby Mud Volcano (SW Barents Sea slope). Journal of Marine Systems 55 (3-4), 271-290. 
Steyaert, M., Garner, N., Van Gansbeke, D., Vincx, M., 1999. Nematode communities from the North Sea: environmental controls on species diversity and vertical distribution within the sediment. Journal of the Marine Biological Association of the United Kingdom 79, 253-264.

Treignier, C., Derenne, S., Saliot, A., 2006. Terrestrial and marine $n$-alcohol inputs and degradation processes relating to a sudden turbidity current in the Zaire canyon. Organic Geochemistry 37, 1170-1184.

Vanaverbeke, J., Soetaert, K., Heip, C., Vanreusel, A., 1997. The metazoan meiobenthos along the continental slope of the Goban Spur (NE Atlantic). Journal of Sea Research 38, 93-107.

Van Gaever, S., Vanreusel, A., Hughes, J.A., Bett, B.J., Kiriakoulakis, K., 2004. The macroand micro-scale patchiness of meiobenthos associated with the Darwin Mounds (north-east Atlantic). Journal of the Marine Biological Association of the United Kingdom 84, 547-556.

Van Gaever, S., Moodley, L., de Beer, D., Vanreusel, A., 2006. Meiobenthos at the Arctic Håkon Mosby Mud Volcano with a parental caring nematode thriving in sulphide-rich sediments. Marine Ecology Progress Series 321, 143-155.

Vanhove, S., Beghyn, M., Van Gansbeke, D., Bullough, L.W., Vincx, M., 2000. A seasonally varying biotope at Signy Island, Antarctic: implications for meiofaunal structure. Marine Ecology Progress Series 202, 13-25.

Vanreusel, A., 1990. Ecology of the free-living marine nematodes from the Voordelta (Southern Bight of the North Sea). I. Species composition and structure of the nematode communities. Cahiers de Biologie Marine 31, 439-463.

Verschelde, D., Gourbault, N., Vincx, M., 1998. Revision of Desmodora with descriptions of new desmodorids (Nematoda) from hydrothermal vents of the Pacific. Journal of the Marine Biological Association of the United Kingdom 78, 75-112.

Vetter, E.W., Dayton, P.K., 1998. Macrofaunal communities within and adjacent to a detritusrich submarine canyon system. Deep-Sea Research II 45, 25-54.

Vincx, M., 1986. Free-living marine nematodes from the Southern Bight of the North Sea. I. Notes on species of the genera Gonionchus Cobb, 1920, Neochromadora Micoletzky, 1924 and Sabatieria Rouville, 1903. Hydrobiologia 140, 255-286.

Warwick, R.M., Gee, J.M., 1984. Community structure of estuarine meiobenthos. Marine Ecology Progress Series 18, 97-111.

Wieser, W., 1960. Benthic studies in Buzzards Bay. II The meiofauna. Limnology and Oceanography 5, 121-137.

Figure captions 
Table 1

Dive and core numbers, latitudes (S), longitudes (E), depths (m), sampling devices, mean grain sizes $(\mu \mathrm{m})$ and sampling habitat. R: sites sampled along a transect between the cold seep and the canyon; M: cold seep sites characterised by high mytilid densities; $\mathrm{V}$ : cold seep sites characterised by high vesicomyid densities

\begin{tabular}{|c|c|c|c|c|c|c|c|c|}
\hline Site & $\begin{array}{l}\text { Dive } \\
\text { number }\end{array}$ & $\begin{array}{l}\text { Core number } \\
\text { (replicates) }\end{array}$ & $\begin{array}{l}\text { Latitude } \\
\qquad\left({ }^{\circ} \mathrm{S}\right)\end{array}$ & $\begin{array}{l}\text { Longitude } \\
\quad\left({ }^{\circ} \mathrm{E}\right)\end{array}$ & $\begin{array}{l}\text { Water } \\
\text { depth } \\
\text { (m) }\end{array}$ & $\begin{array}{l}\text { Sampling } \\
\text { device }\end{array}$ & $\begin{array}{l}\text { Mean } \\
\text { grain } \\
\text { size } \\
(\mu \mathrm{m}) \\
\end{array}$ & $\begin{array}{l}\text { Sampling } \\
\text { habitat }\end{array}$ \\
\hline A & & MTB $22(A, B)$ & $07^{\circ} 20.80^{\prime}$ & $11^{\circ} 30.01^{\prime}$ & 1304 & multicorer & 4.398 & control site \\
\hline C & & MTB $21(\mathrm{~A}, \mathrm{~B})$ & $07^{\circ} 39.90^{\prime}$ & $10^{\circ} 00.41^{\prime}$ & 3994 & multicorer & 4.483 & control site \\
\hline $\begin{array}{l}\text { Levee } \\
\text { (D) }\end{array}$ & & MTB $20(A, B)$ & $05^{\circ} 50.80^{\prime}$ & $08^{\circ} 20.79^{\prime}$ & 3964 & multicorer & 6.031 & $\begin{array}{l}\text { levee (13 km } \\
\text { south of Congo } \\
\text { channel) }\end{array}$ \\
\hline $\begin{array}{l}\text { Chann } \\
\text { el (D') }\end{array}$ & & MTB $19(A, B)$ & $05^{\circ} 43.13^{\prime}$ & $08^{\circ} 27.01^{\prime}$ & 4067 & multicorer & 6.097 & $\begin{array}{l}\text { bottom of } \\
\text { channel }\end{array}$ \\
\hline Lobe & & MTB $33(\mathrm{~A}, \mathrm{~B})$ & $06^{\circ} 28.29^{\prime}$ & $06^{\circ} 01.69^{\prime}$ & 4788 & multicorer & 4.061 & lobe of channel \\
\hline R3 & & MTB $26(A, B)$ & $05^{\circ} 48.67^{\prime}$ & $09^{\circ} 42.71^{\prime}$ & 3174 & multicorer & 7.629 & transition zone \\
\hline $\mathrm{R} 4$ & & MTB $27(\mathrm{~A}, \mathrm{~B})$ & $05^{\circ} 48.15^{\prime}$ & $09^{\circ} 42.70^{\prime}$ & 3167 & multicorer & 5.926 & transition zone \\
\hline R6 & & MTB $28(\mathrm{~A}, \mathrm{~B})$ & $05^{\circ} 48.00^{\prime}$ & $09^{\circ} 42.74^{\prime}$ & 3163 & multicorer & 5.803 & transition zone \\
\hline M1 & PL146-9 & CT2 & $05^{\circ} 47.85^{\prime}$ & $09^{\circ} 42.61^{\prime}$ & 3152 & $\begin{array}{l}\text { ROV push } \\
\text { core }\end{array}$ & & $\begin{array}{l}\text { cold seep } \\
\text { (mytilids) }\end{array}$ \\
\hline M2 & PL146-9 & СТ14 & $05^{\circ} 47.88^{\prime}$ & $09^{\circ} 42.68^{\prime}$ & 3154 & $\begin{array}{l}\text { ROV push } \\
\text { core }\end{array}$ & & $\begin{array}{l}\text { cold seep } \\
\text { (mytilids) }\end{array}$ \\
\hline M3 & PL147-10 & СТ13 & $05^{\circ} 47.84^{\prime}$ & $09^{\circ} 42.66^{\prime}$ & 3155 & $\begin{array}{l}\text { ROV push } \\
\text { core }\end{array}$ & & $\begin{array}{l}\text { cold seep } \\
\text { (mytilids) }\end{array}$ \\
\hline V1 & PL145-8 & СТ2 & $05^{\circ} 47.98^{\prime}$ & $09^{\circ} 42.47^{\prime}$ & 3151 & $\begin{array}{l}\text { ROV push } \\
\text { core }\end{array}$ & & $\begin{array}{l}\text { cold seep } \\
\text { (vesicomyids) }\end{array}$ \\
\hline V3 & PL147-10 & СТ10 & $05^{\circ} 47.80^{\prime}$ & $09^{\circ} 42.71^{\prime}$ & 3153 & $\begin{array}{l}\text { ROV push } \\
\text { core }\end{array}$ & & $\begin{array}{l}\text { cold seep } \\
\text { (vesicomyids) }\end{array}$ \\
\hline
\end{tabular}


Table 2

Densities of all Gulf of Guinea metazoan meiofaunal taxa and relative abundances of Nematoda, Harpacticoida and nauplii (0 to $10 \mathrm{~cm})$

\begin{tabular}{|c|c|c|c|c|c|c|c|c|c|c|c|c|c|}
\hline \multirow[b]{2}{*}{ Site } & \multicolumn{2}{|c|}{ Control } & \multicolumn{3}{|c|}{ Channel system } & \multicolumn{3}{|c|}{ Transition zone } & \multicolumn{5}{|c|}{ Seep } \\
\hline & A & $\mathrm{C}$ & Levee & Channel & Lobe & R3 & R4 & R6 & M1 & M2 & M3 & V1 & V3 \\
\hline Depth (m) & $\begin{array}{l}1304 \\
\text { mean (SE) }\end{array}$ & $\begin{array}{l}3994 \\
\text { mean (SE) }\end{array}$ & $\begin{array}{l}3964 \\
\text { mean } \\
(\mathrm{SE})\end{array}$ & $\begin{array}{l}4067 \\
\text { mean (SE) }\end{array}$ & $\begin{array}{l}4788 \\
\text { mean (SE) }\end{array}$ & $\begin{array}{l}3174 \\
\text { mean } \\
(\mathrm{SE})\end{array}$ & $\begin{array}{l}3167 \\
\text { mean (SE) }\end{array}$ & $\begin{array}{l}3163 \\
\text { mean (SE) }\end{array}$ & 3152 & 3154 & 3155 & 3151 & 3153 \\
\hline \multicolumn{14}{|l|}{$\begin{array}{l}\text { Density } \\
\text { (ind. } 10 \mathrm{~cm}^{-2} \text { ) }\end{array}$} \\
\hline Amphipoda & & & & & & $0.2(0.2)$ & & & & & & & \\
\hline Bivalvia & $1.5(1.5)$ & $0.2(0.2)$ & & & & $0.7(0.3)$ & $0.2(0.2)$ & $0.7(0.7)$ & & & 1.4 & & \\
\hline Gastrotricha & $0.7(0.7)$ & & & & & $0.2(0.2)$ & $0.5(0.5)$ & $0.2(0.2)$ & 1.4 & 3.3 & & & \\
\hline Harpacticoida & $50.7(7.9)$ & $58.3(2.6)$ & $17.4(1.8)$ & & $0.5(0.2)$ & $27.5(4.3)$ & $26.7(2.8)$ & $20.0(7.5)$ & 0.5 & 1.4 & 6.6 & 2.4 & 3.3 \\
\hline Hydrozoa & $0.7(0.7)$ & $1.2(1.2)$ & & & & & & & & & & & \\
\hline Isopoda & $0.7(0.7)$ & & & & & $0.2(0.2)$ & & & & & & & \\
\hline Kinorhyncha & $6.5(0.5)$ & $1.0(0.0)$ & $0.2(0.2)$ & & & $2.0(1.0)$ & $0.7(0.3)$ & $1.8(0.5)$ & & & 2.4 & 79.6 & 34.8 \\
\hline Nauplii & $\begin{array}{l}60.4 \\
(27.0)\end{array}$ & $20.0(9.8)$ & $19.4(7.1)$ & & $0.2(0.2)$ & $16.2(3.3)$ & $13.4(3.8)$ & $12.3(4.3)$ & & & 0.5 & 1.9 & 2.8 \\
\hline Nematoda & $\begin{array}{l}1181.6 \\
(419.0)\end{array}$ & $\begin{array}{l}916.6 \\
(66.9)\end{array}$ & $\begin{array}{l}466.4 \\
(90.2)\end{array}$ & $2.5(2.5)$ & $13.7(8.8)$ & $\begin{array}{l}625.3 \\
(50.8)\end{array}$ & $\begin{array}{l}724.8 \\
(49.3)\end{array}$ & $\begin{array}{l}757.9 \\
(42.1)\end{array}$ & 35.3 & 9.9 & 842.7 & 442.6 & 650.2 \\
\hline Ostracoda & $4.0(1.0)$ & $5.5(1.8)$ & $1.2(0.2)$ & & & $3.0(0.0)$ & $2.2(1.2)$ & $1.7(0.1)$ & & & & & \\
\hline Polychaeta & $6.6(0.3)$ & $2.2(0.5)$ & $1.7(0.7)$ & $0.2(0.2)$ & $0.3(0.0)$ & $1.5(0.2)$ & $1.2(0.5)$ & $1.2(0.2)$ & 5.6 & 5.2 & 18.4 & & 0.5 \\
\hline Tanaidacea & $1.2(0.5)$ & & $0.2(0.2)$ & & & $0.2(0.2)$ & $0.5(0.2)$ & $0.7(0.3)$ & & & & & \\
\hline Tantulocarida & $0.5(0.5)$ & & $0.2(0.2)$ & & & & & & & & & & \\
\hline Tardigrada & $4.5(1.8)$ & & & & & & & & & & & & \\
\hline Turbellaria & $0.5(0.5)$ & & $0.3(0.0)$ & & & & & & & & 1.4 & & 0.9 \\
\hline Total & $\begin{array}{l}1320 \\
(460)\end{array}$ & 1005 (78) & $506(100)$ & $3(3)$ & $15(9)$ & $677(45)$ & $770(40)$ & $796(55)$ & 43 & 20 & 873 & 526 & 693 \\
\hline \multicolumn{14}{|l|}{$\begin{array}{l}\text { Relative } \\
\text { abundance } \\
(\%)\end{array}$} \\
\hline $\begin{array}{l}\text { Copepoda + } \\
\text { nauplii }\end{array}$ & 8.4 & 7.8 & 7.3 & 0.0 & 4.5 & 6.5 & 5.2 & 4.1 & 1.2 & 7.0 & 0.8 & 0.8 & 0.9 \\
\hline Nematoda & 89.5 & 91.2 & 92.1 & 93.8 & 93.3 & 92.4 & 94.1 & 95.2 & 82.1 & 49.5 & 96.5 & 84.1 & 93.8 \\
\hline
\end{tabular}



Table 3

Mean relative abundances of most abundant nematode genera per site in the Gulf of Guinea.

*: two most abundant nematode genera in each site

\begin{tabular}{|c|c|c|c|c|c|c|c|c|c|c|c|c|c|}
\hline \multirow[b]{2}{*}{ Site } & \multicolumn{2}{|c|}{ Control } & \multicolumn{3}{|c|}{ Channel system } & \multicolumn{3}{|c|}{ Transition zone } & \multicolumn{5}{|c|}{ Seep } \\
\hline & A & C & Levee & Channel & Lobe & R3 & R4 & R6 & M1 & M2 & M3 & V1 & V3 \\
\hline Depth (m) & 1304 & 3994 & 3964 & 4067 & 4788 & 3174 & 3167 & 3163 & 3152 & 3154 & 3155 & 3151 & 3153 \\
\hline Sabatieria & 3.3 & 0.1 & 0.5 & & & 1.0 & 0.3 & 0.3 & $17.0^{*}$ & & $69.4^{*}$ & $87.0^{*}$ & $60.4^{*}$ \\
\hline Microlaimus & 4.8 & $33.6^{*}$ & 1.5 & $35.6^{*}$ & $25.9^{*}$ & $10.7^{\star}$ & 3.4 & 3.0 & & & & & 0.2 \\
\hline Thalassomonhystera & $9.7^{*}$ & 7.5 & $21.5^{\star}$ & $31.1^{*}$ & 1.1 & $11.8^{*}$ & $13.6^{*}$ & $17.5^{\star}$ & & & & 0.1 & \\
\hline Desmodora & 0.9 & & & & & 0.1 & & & $80.1^{\star}$ & $58.3^{*}$ & $25.8^{*}$ & 1.9 & $26.2^{*}$ \\
\hline Acantholaimus & 5.8 & $14.1^{*}$ & $18.4^{*}$ & & 5.0 & 7.1 & $11.9^{*}$ & $9.8^{*}$ & & & & & \\
\hline Halalaimus & 7.4 & 1.7 & 4.2 & 20.0 & 3.3 & 3.5 & 7.6 & 5.2 & & & & & \\
\hline Leptolaimus & $13.2^{*}$ & 0.5 & 1.0 & & & 9.4 & 6.2 & 8.7 & & & & & 0.2 \\
\hline Amphimonhystrella & 3.9 & 0.6 & 3.5 & & & 8.2 & 8.4 & 9.0 & & & & & \\
\hline Theristus & 3.3 & 6.9 & 7.8 & & 8.9 & 2.3 & 2.8 & 1.1 & & & & & \\
\hline Tricoma & 4.5 & 3.6 & 3.2 & & & 5.5 & 6.1 & 6.3 & & & & & \\
\hline Metadesmolaimus & 0.6 & 1.9 & 0.4 & & 7.8 & 4.5 & 0.4 & 2.6 & & & 0.4 & $5.7^{*}$ & 7.5 \\
\hline Sphaerolaimus & 1.2 & & 0.9 & & 6.7 & 1.3 & 1.7 & 4.2 & & & & 0.4 & 0.1 \\
\hline Epsilonema & & & & & 6.7 & & & & & $14.3^{*}$ & & & \\
\hline Syringolaimus & 0.1 & 0.5 & 0.6 & & 6.7 & & & 0.1 & & 5.4 & & & \\
\hline Cervonema & 0.7 & 0.7 & 6.4 & & & 1.0 & 0.9 & 0.5 & & & & & 0.1 \\
\hline Kraspedonema & & 0.1 & & & $9.1^{*}$ & & 0.4 & 0.1 & & & & & \\
\hline Thalassoalaimus & & & 0.1 & 13.3 & & & 0.1 & & & & & & \\
\hline Paracanthonchus & 0.8 & 5.3 & 0.3 & & & 0.2 & 0.1 & 0.1 & & & & & \\
\hline
\end{tabular}


Table 4

Diversity indices at nematode genus level: Hill's diversity numbers of order $0,1,2$ and $\infty\left(N_{0}\right.$, $\left.\ldots, \mathrm{N}_{\infty}\right)$ and the expected number of genera per 100 individuals (EG(100))

\begin{tabular}{|c|c|c|c|c|c|c|c|c|c|c|c|c|c|}
\hline \multirow[b]{2}{*}{ Site } & \multicolumn{2}{|c|}{ Control } & \multicolumn{3}{|c|}{ Channel system } & \multicolumn{3}{|c|}{ Transition zone } & \multicolumn{5}{|c|}{ Seep } \\
\hline & $A$ & $\mathrm{C}$ & Levee & Channel & Lobe & R3 & $\mathrm{R} 4$ & $\mathrm{R} 6$ & M1 & M2 & M3 & V1 & V3 \\
\hline Depth (m) & 1304 & 3994 & 3964 & 4067 & 4788 & 3174 & 3167 & 3163 & 3152 & 3154 & 3155 & 3151 & 3153 \\
\hline $\mathrm{N}_{0}$ & 82 & 65 & 69 & 4 & 19 & 73 & 72 & 62 & 4 & 7 & 8 & 8 & 13 \\
\hline $\mathrm{N}_{1}$ & 29.4 & 13.2 & 17.9 & 3.7 & 7.6 & 23.0 & 22.1 & 19.8 & 1.8 & 4.0 & 2.2 & 1.8 & 3.0 \\
\hline $\mathrm{N}_{2}$ & 18.5 & 6.6 & 9.9 & 3.6 & 6.1 & 16.0 & 14.7 & 12.7 & 1.5 & 2.7 & 1.8 & 1.3 & 2.3 \\
\hline $\mathrm{N}_{\infty}$ & 6.9 & 3.0 & 4.8 & 2.8 & 3.8 & 8.3 & 6.5 & 5.7 & 1.2 & 1.7 & 1.4 & 1.1 & 1.7 \\
\hline$E G(100)$ & 33 & 22 & 27 & 4 & 9 & 28 & 27 & 26 & 3 & 7 & 4 & 6 & 7 \\
\hline
\end{tabular}

\section{Figures}

Fig. 1. Map indicating the location of the Congo Channel system and sampling sites in the Gulf of Guinea, with 1000-m isobaths.

Fig. 2. Detailed map of the REGAB cold seep. Points in the carbonate crust area indicate 5 different cold seep sites sampled with push cores of the ROV Victor. Points R3, R4, R6 indicate locations of the multicores in the transition zone between cold seep and Congo canyon.

Fig. 3. Meiofaunal densities with indication of nematode densities (ind. $10 \mathrm{~cm}^{-2}$ ), and total nematode biomass ( $\mu \mathrm{g}$ DW $10 \mathrm{~cm}^{-2}$ ) (mean values $\pm 1 \mathrm{SD}$ ).

Fig. 4. Average meiofaunal densities of the different sites in the Gulf of Guinea arranged according to water depth $(\mathrm{m})$, compared with the best regression line [y $=2821.76$ 286.86*(In depth)] from Soltwedel (1997) for the continental margins off the western African coast between Guinea $\left(10^{\circ} \mathrm{N}\right)$ and Angola $\left(18^{\circ} \mathrm{S}\right)$.

Fig. 5. Depth profiles of nematode densities for the different sites (ind. $\left.10 \mathrm{~cm}^{-2}\right)$ (mean values \pm 1 SD) (in seep profiles: white bars = Sabatieria mortenseni ; black bars = Desmodora sp. ; grey bars = remaining genera).

Fig. 6. Overview of the dominant nematodes (males) in the seep site and in the non-seep sites in the Gulf of Guinea. Photographs on the left show the two dominant nematode species from REGAB, photographs on the right show representative species for the four most abundant nematode genera in the non-seep sites. Photographs of the nematode habitus are all placed on the same scale. Closed arrows point to the amphid at the anterior part or the spicule at the posterior part of the nematode, open arrows point to the precloacal supplements.

Fig. 7. Nonmetric-multidimensional scaling plots based on the Gulf of Guinea nematode community (relative abundances of genera). Plot in background is based on all sites, plot on foreground shows only the control sites, levee site and transition zone. 


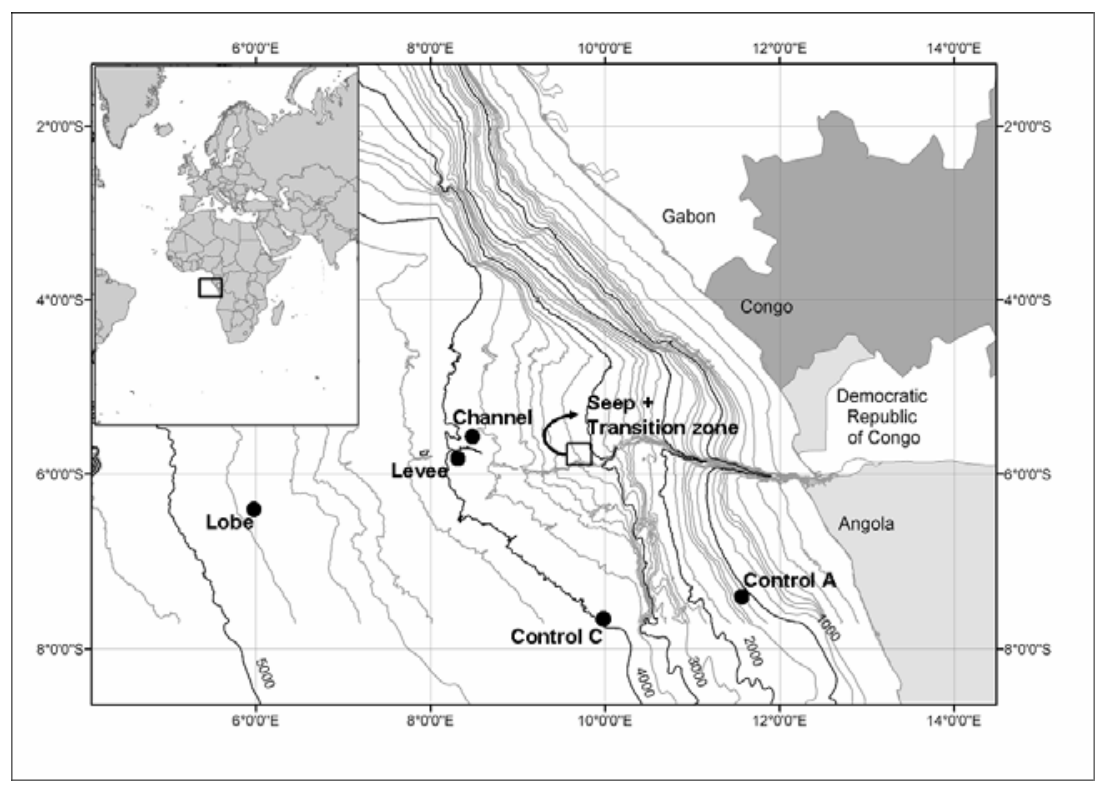

1 


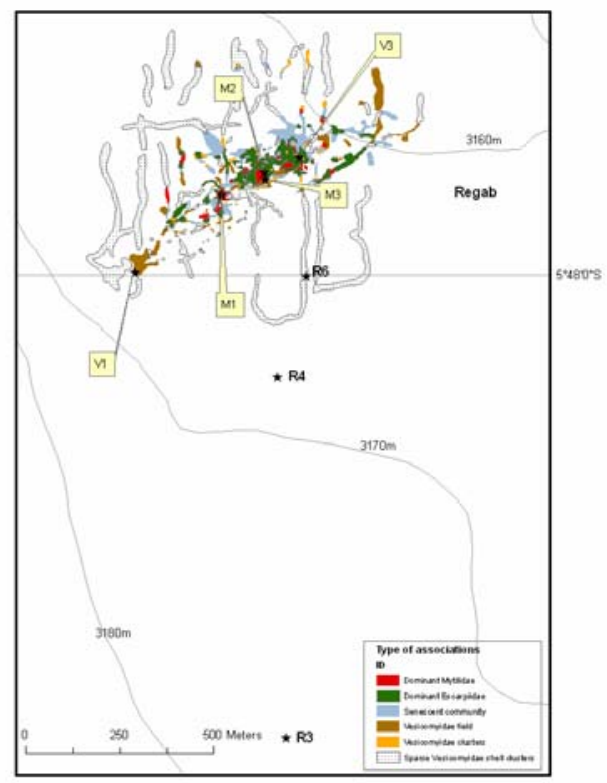

2 


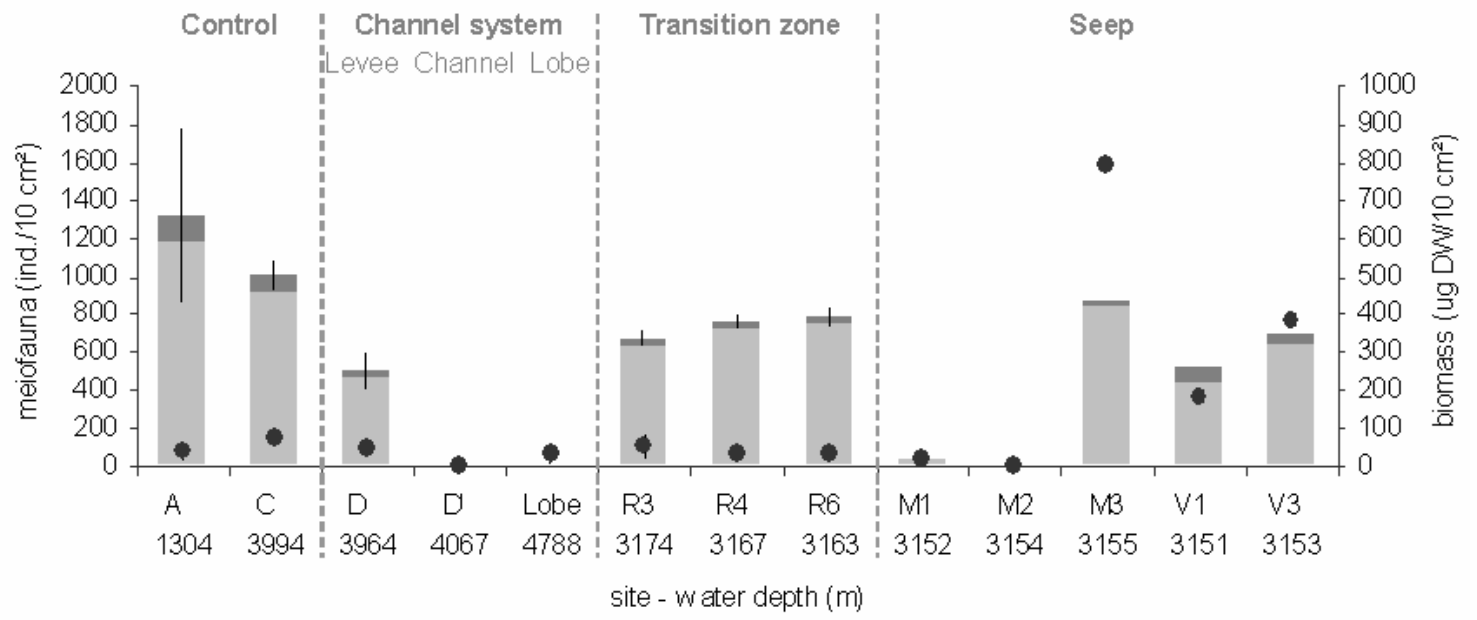

Nematoda $\quad$ Other meiofauna taxa Nematode biomass 


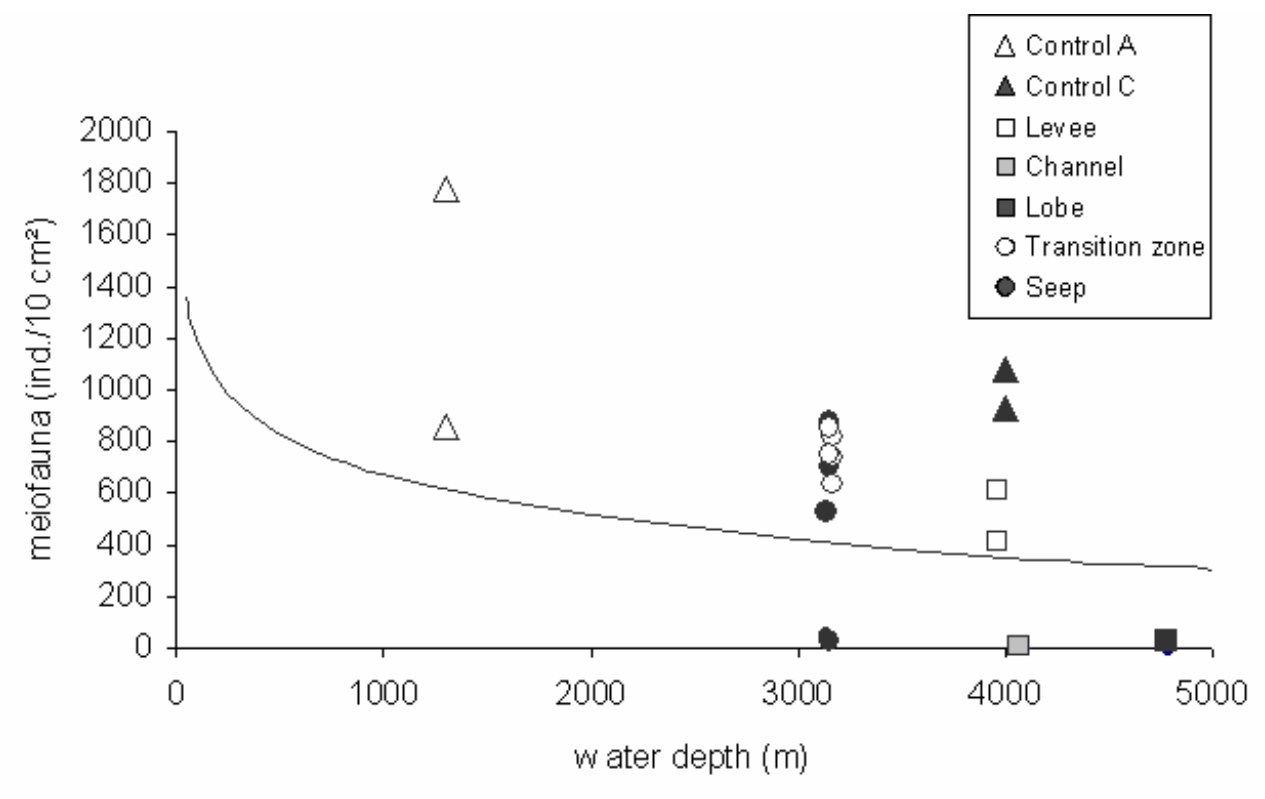

4 


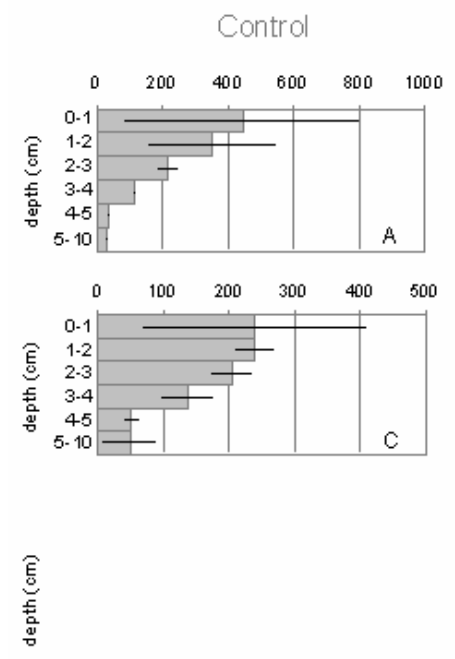

Channel system
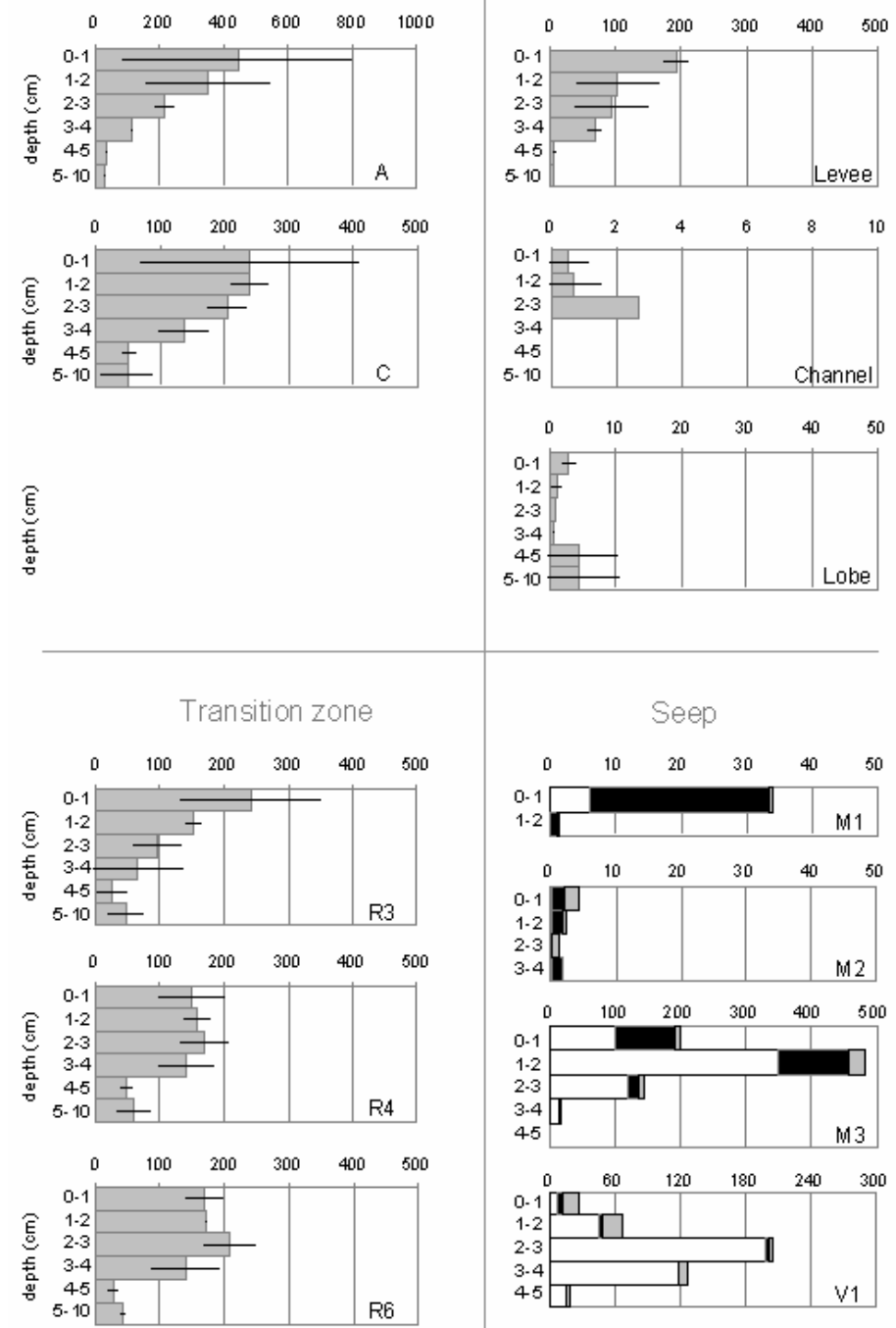

Nematoda (ind./10 $\mathrm{cm}^{2}$ )

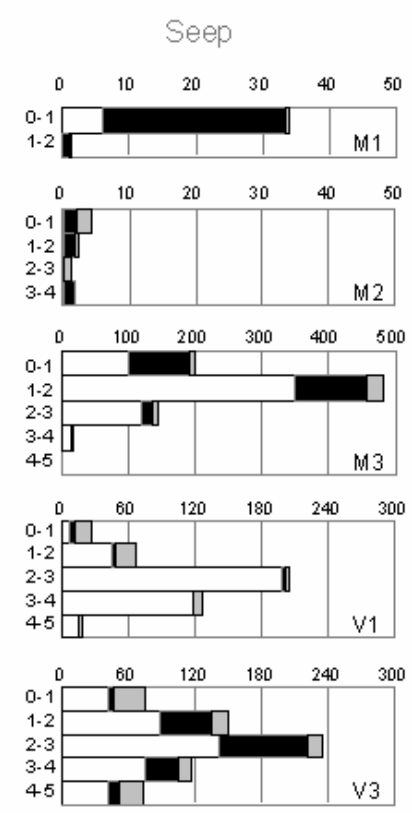

Nematoda (ind. $M 0 \mathrm{~cm}^{2}$ ) 


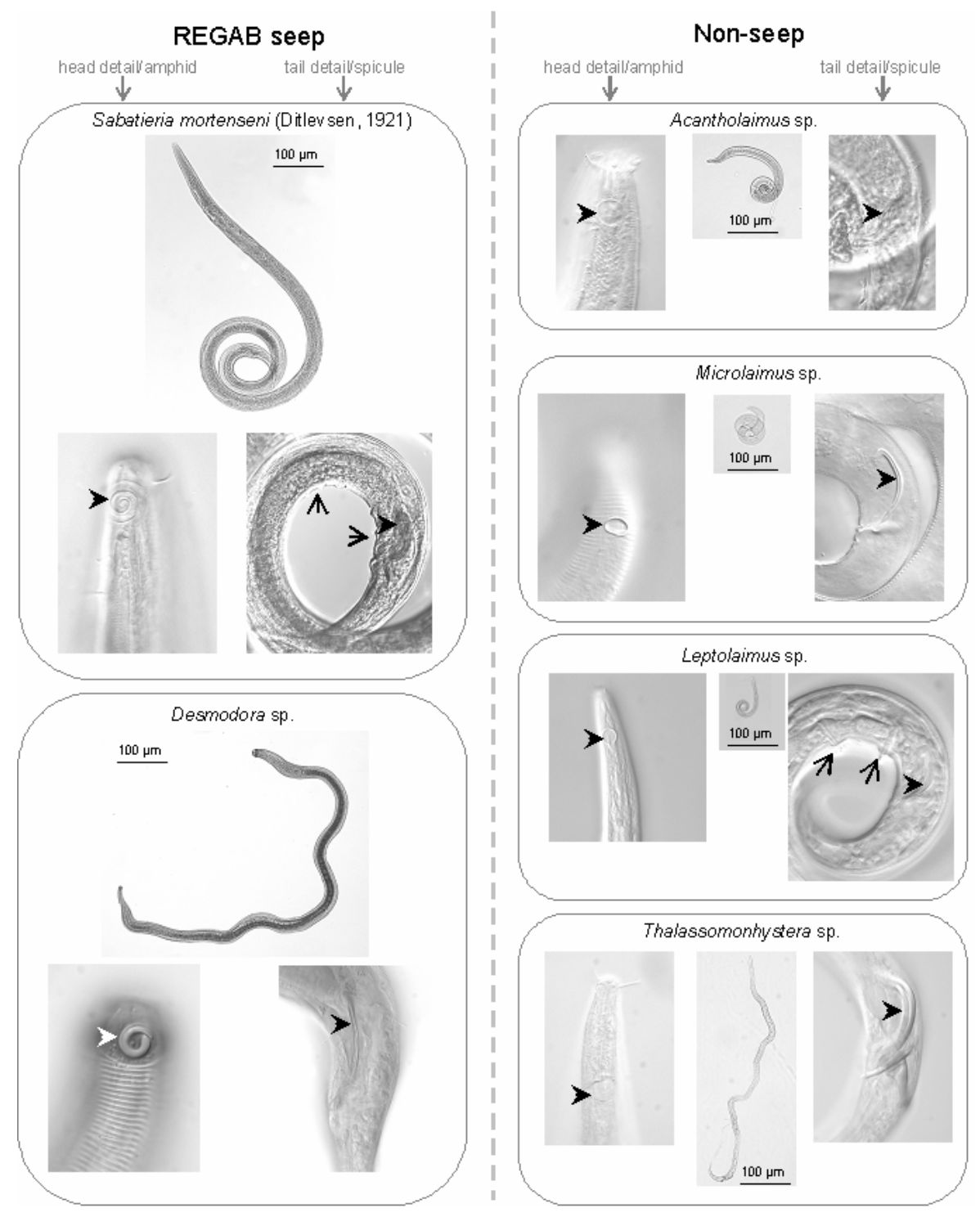

6 


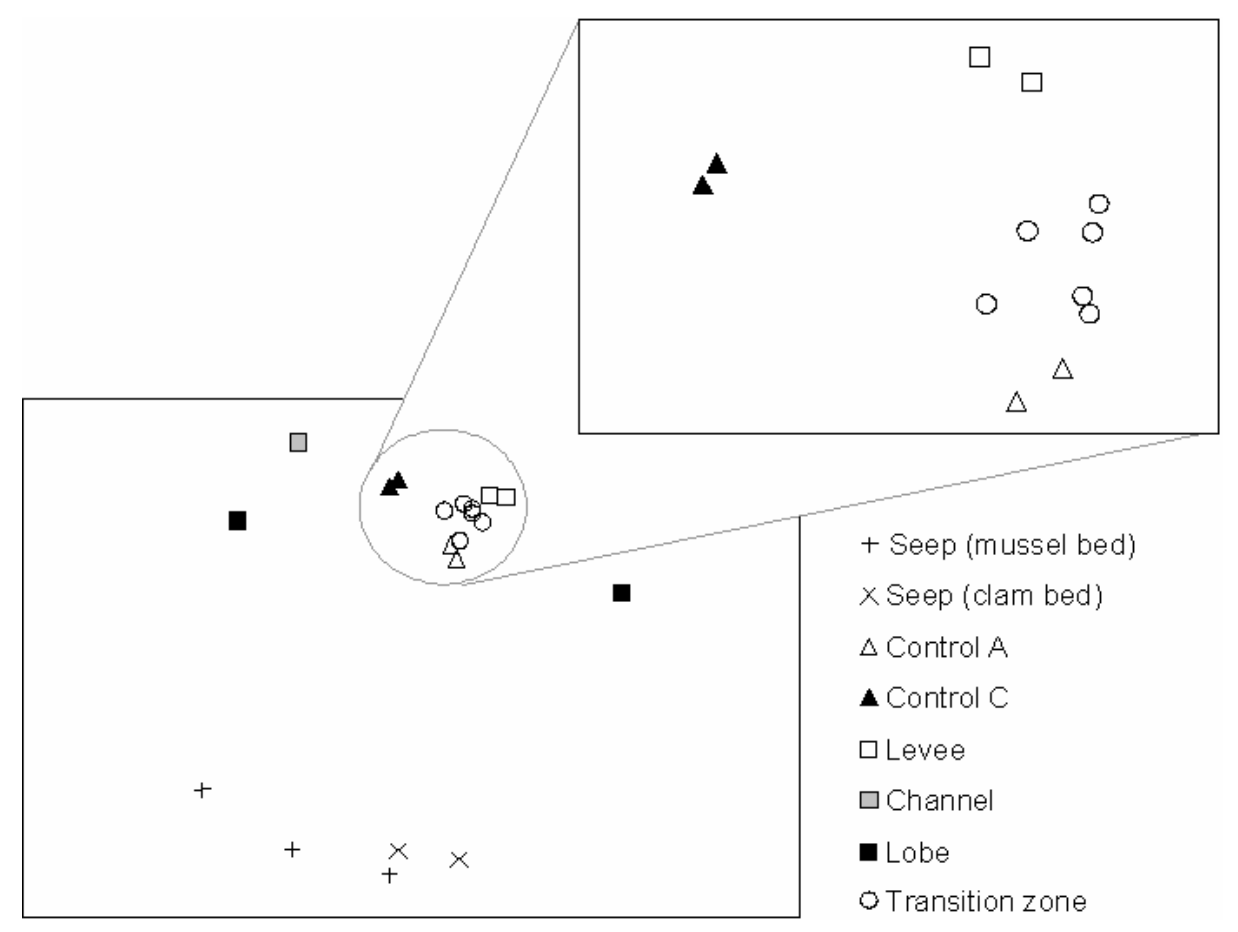

